\title{
Improved Glucose-Stimulated Insulin Secretion by Selective Intraislet Inhibition of Angiotensin II Type 1 Receptor Expression in Isolated Islets of $\mathbf{d b} / \mathbf{d b}$ Mice
}

\author{
Zhen Zhang, ${ }^{1}$ Chunyan Liu, ${ }^{1}$ Zhenhua Gan, ${ }^{1}$ Xinyi Wang, ${ }^{1}$ Qiuyan Yi, ${ }^{1}$ Yanqing Liu, \\ Yingzhijie Wang, ${ }^{1}$ Bin Lu, ${ }^{1}$ Hong Du, ${ }^{1}$ Jiaqing Shao, ${ }^{1}$ and Jun Wang ${ }^{2}$ \\ ${ }^{1}$ Department of Endocrinology, Jinling Hospital, Southern Medical University, 305 Zhongshan East Road, Nanjing, \\ Jiangsu Province 210002, China \\ ${ }^{2}$ Department of Cardiology, Jinling Hospital, Southern Medical University, 305 Zhongshan East Road, Nanjing, \\ Jiangsu Province 210002, China
}

Correspondence should be addressed to Jiaqing Shao; shaojiaq@hotmail.com and Jun Wang; zero991127@hotmail.com

Received 23 July 2013; Revised 13 October 2013; Accepted 31 October 2013

Academic Editor: Umberto Campia

Copyright (c) 2013 Zhen Zhang et al. This is an open access article distributed under the Creative Commons Attribution License, which permits unrestricted use, distribution, and reproduction in any medium, provided the original work is properly cited.

\begin{abstract}
Recent evidence supported the presence of a local renin-angiotensin system (RAS) in the pancreas, which is implicated in many physiological and pathophysiological processes. We utilized small interfering RNA (siRNA) to investigate the effects of angiotensin II type 1 receptor (AT1R) knockdown on glucose-stimulated insulin secretion (GSIS) in isolated islets of db/db mice and to explore the potential mechanisms involved. We found that Ad-siAT1R treatment resulted in a significant decrease both in AT1R mRNA level and in AT1R protein expression level. With downexpression of AT1R, notable increased insulin secretion and decreased glucagon secretion levels were found by perifusion. Simultaneously, significant increased protein levels of IRS-1 (by 85\%), IRS-2 (by 95\%), PI3K(85) (by 112.5\%), and p-Akt2 (by 164\%) were found by western blot. And upregulation of both GLUT-2 (by 190\%) and GCK (by 121\%) was achieved after AT1R inhibition by Ad-siAT1R. Intraislet AT1R expression level is a crucial physiological regulator of insulin sensitivity of $\beta$ cell itself and thus affects glucose-induced insulin and glucagon release. Therefore, the characteristics of AT1R inhibitors could make it a potential novel therapeutics for prevention and treatment of type 2 diabetes.
\end{abstract}

\section{Introduction}

Recent decades have seen a dramatic rise in the incidence and prevalence of type 2 diabetes mellitus (T2DM) throughout the world. The damage of pancreatic islet function plays a crucial role in the pathogenesis and progression of T2DM. However, current treatment of T2DM can not provide effective protection against islet failure. Interestingly, recent clinical researches had shown that RAS blockade by ACE inhibitor (ACEI) or angiotensin receptor blocker (ARB) could reduce the onset of diabetes in people at high risk by $14 \%-34 \%$ [1-4]. The mechanisms underlying this protective effect appear to be complex and may involve improvement of both insulin sensitivity and insulin secretion. However, the detailed mechanisms are still unknown.

RAS components, such as angiotensinogen (AGT), angiotensin converting enzyme (ACE), angiotensin II (AngII) and type 1 and type 2 angiotensin II receptors (AT1R and AT2R), had been found in islets $[5,6]$. Evidence suggests that the local pancreatic islet RAS performs multifactorial activities in structure and function of islet, including cell proliferation, apoptosis, oxidative stress, inflammatory responses, and glucose-stimulated insulin secretion, and these regulatory functions are probably mediated via ATIR [7]. Such a local islet RAS is subject to overactivation by diabetes and thus drives islet fibrosis and reduces islet blood flow, oxygen tension, and insulin biosynthesis. Kampf et al. demonstrated that endogenous levels of Ang II exerted detrimental effects on islet blood perfusion in transplanted mouse islets [8]. Moreover, overactivation of an islet RAS may accelerate the synthesis of reactive oxygen species, aggravate oxidative stressinduced $\beta$-cell dysfunction, and apoptosis and thus contribute to the islet failure seen in type 2 diabetes [9]. Our 
previous studies found that candesartan treatment could improve glucose tolerance with the preservation of $\beta$-cell mass and morphology in $\mathrm{db} / \mathrm{db}$ mice $[10,11]$. However, it is unclear whether or not these benefits are dependent on the changes of circulating RAS components. So selective inhibition of AT1R expression in islet could reveal the definite role of intraislet RAS in glucose homeostasis.

The insulin receptors and their substrates (IRS-1 and IRS2 ) have been proved to be expressed in the $\beta$-cell [12-14]. By the insulin signaling pathway, these molecules could impact GSIS of $\beta$-cell $[15,16]$. Accumulated data have demonstrated that local RAS expressed in peripheral tissues is overactivated in the state of insulin resistance, and the effects of RAS blockade on insulin resistance have been proved $[17,18]$. As there is evidence for insulin signaling molecules expression in islets itself and because RAS is implicated in the pathogenesis of insulin resistance, it is possible that local RAS expressed in islets may affect GSIS through insulin signaling pathway of $\beta$-cell.

In the present study, we aim to explore whether intrinsic RAS in islet is involved in glucose-stimulated insulin secretion by affecting insulin sensitivity of $\beta$-cell itself via RNA interference technique which can inhibit the expression of intraislet AT1R effectively and specifically.

\section{Materials and Methods}

2.1. Islet Isolation and Culture. Five eight-week old female $\mathrm{db} / \mathrm{db}$ mice and five age and gender matched nondiabetic littermates $\mathrm{db} / \mathrm{m}$ mice were obtained from the Animal Experiment Center of Jingling Hospital. Mice were anesthetized with pentobarbital (Nembutal, Abbot Laboratories). After clamping the common bile duct at a point close to the duodenal outlet, pancreas was injected through the pancreatic duct with $2 \mathrm{~mL}$ Krebs-Ringer bicarbonate buffer (KRBB: $129 \mathrm{mmol} / \mathrm{L} \mathrm{NaCl}, 5 \mathrm{mmol} / \mathrm{L} \mathrm{NaHCO} 3,4.8 \mathrm{mmol} / \mathrm{L}$ $\mathrm{KCl}, 1.2 \mathrm{mmol} / \mathrm{L} \mathrm{KH} 2 \mathrm{PO} 4,1.2 \mathrm{mmol} / \mathrm{L} \mathrm{MgSO} 4,0.2 \% \mathrm{BSA}$, $10 \mathrm{mmol} / \mathrm{L} \mathrm{Hepes,} 2.5 \mathrm{mmol} / \mathrm{L} \mathrm{CaCl} 2$, and $2.8 \mathrm{mmol} / \mathrm{L}$ glucose at $\mathrm{pH} 7.4$ ) containing $1.5 \mathrm{mg} / \mathrm{mL}$ of collagenase (Worthington, Biochemical Co., St. Louis, Missouri). The swollen pancreas was removed and incubated at $37^{\circ} \mathrm{C}$ for $40 \mathrm{~min}$. The digested pancreas was shaken and washed with ice-cold HBSS four times, and islets were handpicked under a stereomicroscope cultured in RPMI 1640 medium at $37^{\circ} \mathrm{C}$ in a humidified atmosphere (5\% CO2, 95\% air). For both batch incubation and perifusion studies, the islets were pre-incubated for $30 \mathrm{~min}$ in $\mathrm{KRBB}\left(1.4 \mathrm{mmol} / \mathrm{L}\right.$ glucose) at $37^{\circ} \mathrm{C}, 5 \% \mathrm{CO} 2$, and saturated humidity.

2.2. Isolation of Total RNA and Real-Time Reverse Transcription PCR of ATIR. Total RNA was extracted from islets by the TRIzol reagent according to the manufacturer's protocol (Invitrogen). For quantitative real-time PCR, the first strand cDNA was synthesized from $300 \mathrm{ng}$ of total RNA using the oligo (dT) primer and MMLV reverse transcriptase (Invitrogen). Samples were subjected to quantitative amplification using the TaqMan probe and primer sets for mice AT1R. PCR amplification was performed in a total volume of
$10 \mu \mathrm{L}$ containing $30 \mathrm{ng}$ of cDNA, $900 \mathrm{nM}$ of each primer, $250 \mathrm{nM}$ of the respective probe, and $6 \mu \mathrm{L}$ of Taq Man Universal PCR Master Mix. Real-time PCRs $\left(95^{\circ} \mathrm{C}\right.$ for $15 \mathrm{~s}, 55^{\circ} \mathrm{C}$ for $20 \mathrm{~s}$, and $72^{\circ} \mathrm{C}$ for $20 \mathrm{~s} \times 35$ cycles) were performed in an ABI-Prism 7700 sequence detector system (Applied Biosystems, Foster City, CA). Different cDNA samples were normalized using primer sets to the housekeeping gene $\beta$-actin. Primers were as follows: ATIR, $5^{\prime}$-AGCTACAACAAGGCAAGG- $3^{\prime}$ and $3^{\prime}$-TAGAAGGCACAGTCGAGG- $5^{\prime} ; \beta$-actin, $5^{\prime}$-TGTTGTCCCTGTATGCCTCTGGTC- $3^{\prime}$ and $3^{\prime}$-ATGTCACGCACGATTTCCCTCTCA- $5^{\prime}$. The fold changes were calculated by using the comparative threshold cycle method.

2.3. Cell Culture. INS-1 cells were grown in monolayer cultures in RPMI 1640 complete medium at $11.1 \mathrm{mmol} / \mathrm{L}$ glucose supplemented with $10 \%(\mathrm{w} / \mathrm{v})$ fetal bovine serum, $10 \mathrm{mmol} / \mathrm{L}$ HEPES, $2 \mathrm{mmol} / \mathrm{L} \mathrm{L}$-glutamine, $1 \mathrm{mmol} / \mathrm{L}$ sodium pyruvate, and $50 \mu \mathrm{mol} / \mathrm{L} \beta$-mercaptoethanol at $37^{\circ} \mathrm{C}$ in a humidified atmosphere (5\% CO2, 95\% air). For transfection experiments, the cells were seeded in $75-\mathrm{cm}^{2}$ flasks at $4 \times 10^{6}$ cells 2 days prior to transfection and were at $60-70 \%$ confluency at the time of the transfection.

2.4. Short Hairpin RNA-Mediated Gene Suppression. shRNAs directed against mice ARIR (GenBank accession number NM_030985) were designed according to Ambion (Austin, TX) siRNA design guidelines. Briefly, from $5^{\prime}$ - to $3^{\prime}$-end, the whole length of shRNA was sequentially composed of the BamHI restriction site, the 19-nucleotide antisense genetargeting sequence, TTT TTT ending transcription sequence, and HindIII restriction site. Three different shRNAs candidates (siAT1R1, siAT1R2, and siAT1R3) were designed and tested for their potency to decrease the targeted gene expression. A duplex with no known target (GAG ACC CTA TCC GTG ATT A) was used as control (siControl). All of the oligonucleotides were synthesized and purified. After annealing, the double-stranded oligonucleotides were ligated by self-formed restriction sites for BamHI and HindIII in pSilencer 2.0 vector (Ambion). The siRNAs were transfected into INS-1 cells using Lipofectamine PLUS at a concentration of $5 \mu \mathrm{g}$ of DNA for $6 \times 10^{6}$ cells. Three days after transfection, INS-1 cells were harvested for RNA and protein. AT1R expression was confirmed by qRT-PCR and immunoblot analysis as described above. The most efficient one (siAT1R2) was chosen for subsequent experiments. Relative to the start codon, the $5^{\prime}$ ends of the target correspond to mice AT1R nucleotide 540 (GCGTCTTTCTTCTCAATCT).

2.5. Recombinant Adenovirus Construction. Recombinant adenoviruses containing the siATR12 (Ad-siATR1) or the siControl (Ad-siControl) sequences described above were constructed using AdEasy System. Briefly, for each pSilencerbased clone, the siRNA expression cassette was excised and ligated into linearized adenoviral shuttle vector pAdTrack. Subsequently, $1 \mu \mathrm{g}$ recombinant PmeI-linearized pAd-siATR1 was transfected into Escherichia coli BJ5183 cells with an adenoviral backbone plasmid, pAdEasy-1. Recombinants were selected and successful recombination was determined by 
restriction endonuclease analysis. The linearized recombinant adenoviral construct was transfected into 293 cells and high-titer viral stocks were prepared. Viral titers were determined by plaque assay and expressed as plaque-forming units per $\mathrm{mL}(\mathrm{pfu} / \mathrm{mL})$. The viral titers of Ad-siATR1 and AdsiControl were $3.6 \times 10^{9} \mathrm{pfu} / \mathrm{mL}$ and $2.9 \times 10^{9} \mathrm{pfu} / \mathrm{mL}$, respectively.

2.6. Gene Silencing in Islets of Langerhans. Islets of $\mathrm{db} / \mathrm{db}$ mice and $\mathrm{db} / \mathrm{m}$ mice in aliquots of 50 islets per well of a sixwell plate in $2 \mathrm{~mL}$ medium were divided into three groups: (1) Ad-siAT1R group, islets were treated with Ad-siAT1R for $20 \mathrm{~h}$ at 2,000 plaque-forming units/islet; (2) Ad-siControl group, islets were treated with Ad-siControl; (3) Control group, Mock transduced islets. Mock infected islets were not exposed to virus during the incubation period and were not incubated with any vectors. After removal of virus-containing medium, islets were cultured for an additional $72 \mathrm{~h}$ with medium changes every $24 \mathrm{~h}$. GSIS was measured. Subsequently, islets were collected and lysed for analysis of AT1R expression as described above.

2.7. Islet Perifusion. Kinetics of insulin release in vitro was studied by the perifusion system. Size-matched 50 islets were placed in each column. Then the columns were gently closed with the top adaptors, immersed in vertical position and controlled temperature in the water bath at $37^{\circ} \mathrm{C}$. The perifusion medium was maintained at $37^{\circ} \mathrm{C}$ in a water bath. And all columns were perfused in parallel at a flow rate of $0.5 \mathrm{~mL} / \mathrm{min}$ with $\mathrm{KRB}(2.8 \mathrm{mmol} / \mathrm{L}$ glucose $)$ at $37^{\circ} \mathrm{C}$. After $60 \mathrm{~min}$ static incubation with $\mathrm{KRB}(2.8 \mathrm{mmol} / \mathrm{L}$ glucose $)$, the islets were stimulated in the continuous presence of a high concentration of $16.7 \mathrm{mmol} / \mathrm{L}$ glucose. Samples were collected every $20 \mathrm{sec}-$ ond until $2 \mathrm{~min}$, every $1 \mathrm{~min}$ until $5 \mathrm{~min}$, and thereafter every $5 \mathrm{~min}$ until $30 \mathrm{~min}$. Samples were immediately stocked at $-80^{\circ} \mathrm{C}$ until further analysis.

2.8. Western Blot Analysis of ATIR, IRS-1, IRS-2, PI3-K p85, p-Akt2, GLUT-2, and GCK in Islets. Isolated islets were dissolved in lysis buffer $(25 \mathrm{mmol} / \mathrm{L}$ HEPES, $50 \mathrm{mmol} / \mathrm{L} \mathrm{KCl}$, $6 \%$ glycerol, $5 \mathrm{mmol} / \mathrm{L}$ EDTA, $5 \mathrm{mmol} / \mathrm{L}$ EGTA, $0.5 \%$ Triton$\mathrm{X} 100,50 \mu \mathrm{mol} / \mathrm{L} \mathrm{NaF}, 40 \mathrm{mmol} / \mathrm{L}$ glycerophosphate, and $25 \mathrm{mmol} / \mathrm{L}$ sodium pyrophosphate with proteinase inhibitors). Total protein was measured (BCA protein assay, Pierce, Rockford, IL), and $50 \mu \mathrm{g}$ protein were fractionated by SDSPAGE and electrophoretically transferred onto nitrocellulose membranes (Invitrogen). Membranes were incubated in blocking buffer (1TBS, $0.1 \%$ Tween 20, and 5\% nonfat dry milk) for $1 \mathrm{~h}$ at room temperature. The following primary antibodies were used: rabbit anti-AT1R antibody, anti-insulin receptor substrate 1 antibody, anti-insulin receptor substrate 2 antibody, anti-PI3-kinase p85 $\alpha$, anti-phospho-Akt2, antiglucokinase antibody, anti-glucose transporter- 2 (GLUT-2) antibody, and anti- $\beta$-actin antibody (Santa Cruz Biotechnology, Santa Cruz, CA). After three washes in TBS/0.1\% Tween 20 , the membranes were hybridized with a horseradish peroxidase-conjugated anti-rabbit immunoglobulin $\mathrm{G}$ prepared in goat (Santa Cruz Biotechnology, Santa Cruz, CA) for $1 \mathrm{~h}$ at

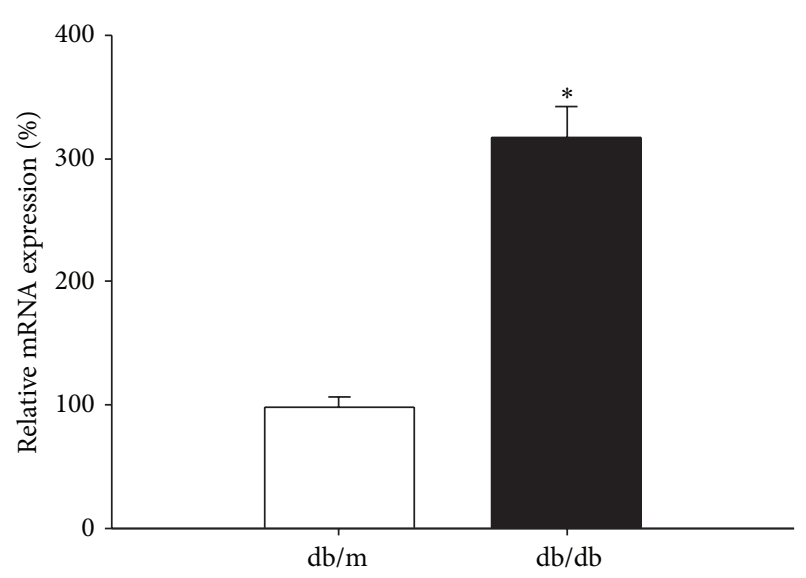

(a)
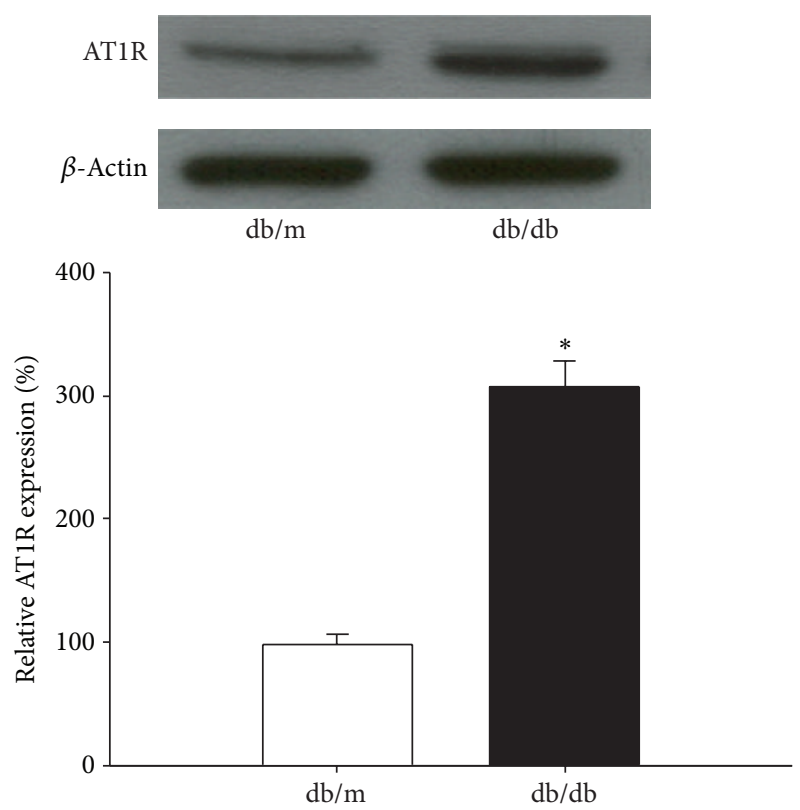

(b)

FIgure 1: Expression in islet of AT1R in $\mathrm{db} / \mathrm{m}$ mice and $\mathrm{db} / \mathrm{db}$ mice. (a) Expression in islets of AT1R mRNA in $\mathrm{db} / \mathrm{m}$ mice or $\mathrm{db} / \mathrm{db}$ mice. Gene expression was measured by quantitative RT-PCR. Graphical presentation shows the relative AT1R mRNA abundance after normalization to actin. Data are presented as mean $\pm \mathrm{SD},{ }^{*} \mathrm{P}<$ 0.05 versus $\mathrm{db} / \mathrm{m}$ group, $n=5$. (b) Expression of AT1R protein in islets from $\mathrm{db} / \mathrm{m}$ mice or $\mathrm{db} / \mathrm{db}$ mice. Lysates from freshly isolated islets were analyzed for AT1R expression by western blot analysis. Results represent the mean $\pm \mathrm{SD}$. Blots from one representative experiments are shown. ${ }^{*} P<0.05$ versus $\mathrm{db} / \mathrm{m}$ group, $n=5$.

room temperature. After three washes in TBS/0.1\% Tween 20, the bands were visualized by enhanced chemiluminescence (Super Signal West Femto; Pierce, Rockford, IL). The intensities of blots were quantified by scanning densitometry and normalized to the values for actin.

2.9. Statistical Analysis. Data are expressed as means \pm SD. Statistical analysis was performed with SPSS XI. Data were 


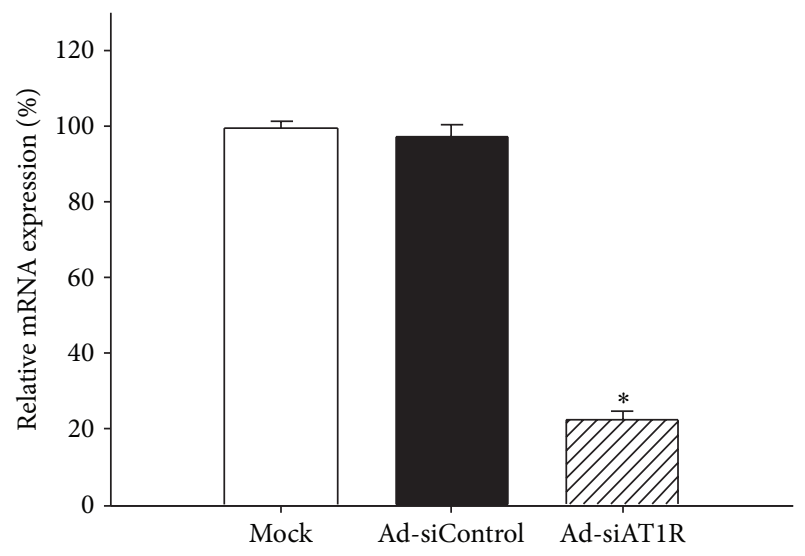

(a)
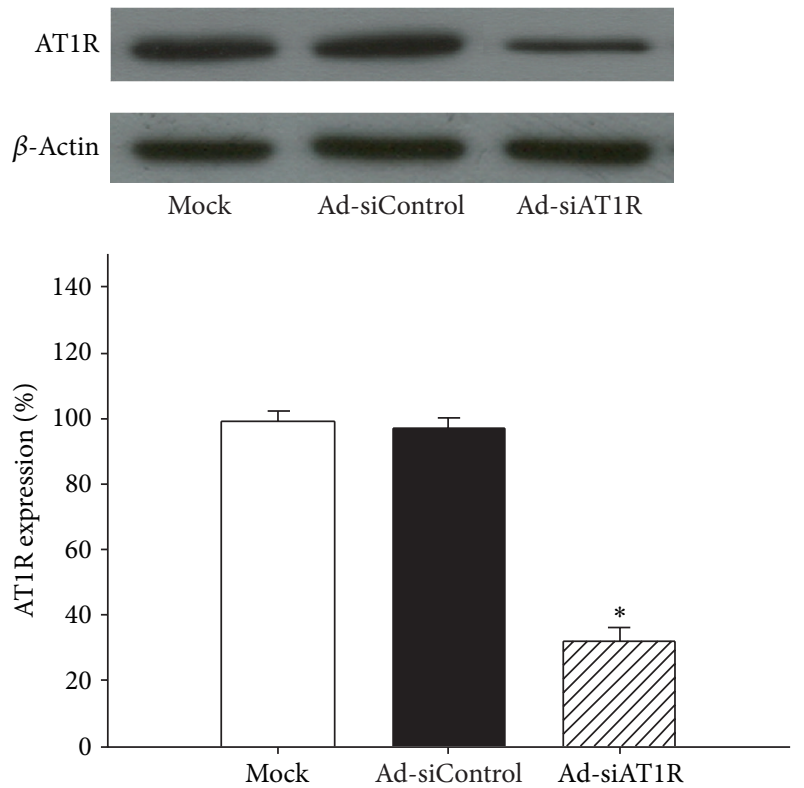

(b)

FIGURE 2: Effects of AT1R silencing on AT1R expression. (a) Islets of $\mathrm{db} / \mathrm{db}$ mice were transfected with Ad-si AT1R, Ad-siControl, or Mock and cells were cultured for $72 \mathrm{~h}$ prior to quantitative RTPCR. Results are represented as mean \pm SD for six independent experiments. ${ }^{*} P<0.05$ versus Ad-siControl. (b) Islets of $\mathrm{db} / \mathrm{db}$ mice were transfected with Ad-si AT1R, Ad-siControl, or Mock and cells were cultured for $72 \mathrm{~h}$ prior to quantitative immunoblot evaluation. Results are represented as mean \pm SD for six independent experiments. ${ }^{*} P<0.05$ versus Ad-siControl.

grouped according to treatment and analyzed by an independent sample $t$-test or a one-way ANOVA. A value of $P<0.05$ is considered statistically significant for all comparisons.

\section{Results}

3.1. AT1R Expression in Islets of $d b / d b$ and $d b / m$ Mice. The expression level of AT1R, both in mRNA and in protein, in isolated islets of $\mathrm{db} / \mathrm{db}$ mice was nearly two times higher than that of $\mathrm{db} / \mathrm{m}$ mice $(P<0.05)$, indicating that AT1R was overexpressed in diabetic pancreatic islets (Figure 1).

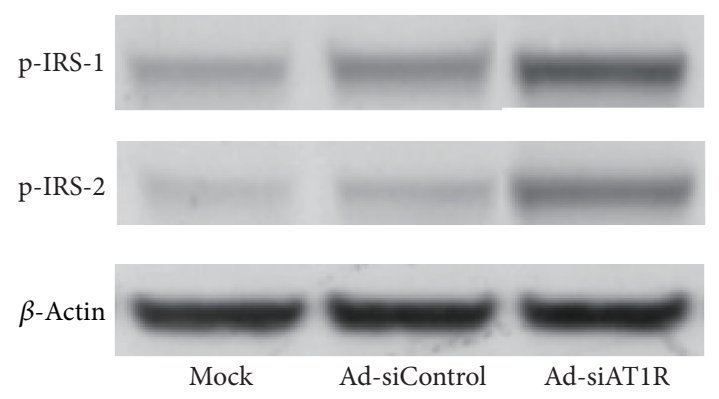

(a)

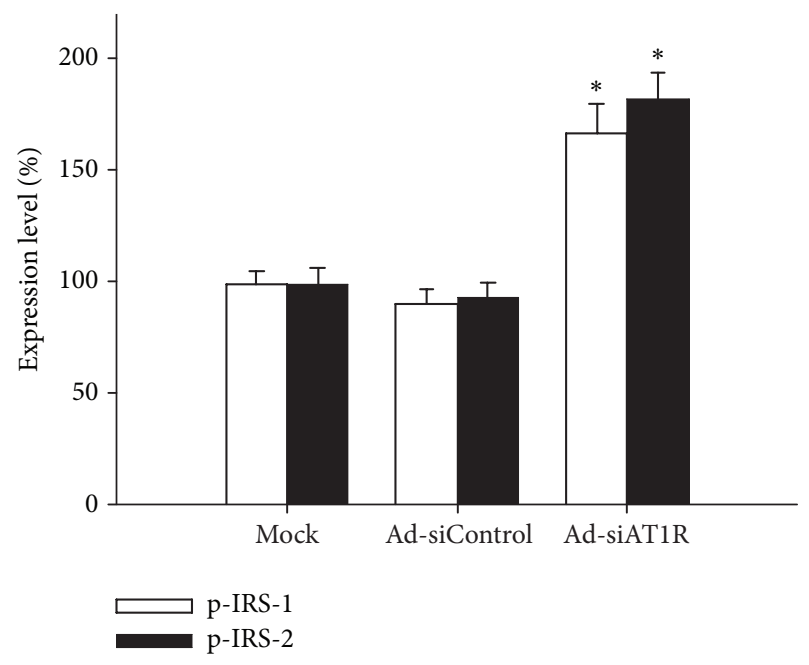

(b)

FIGURE 3: Effects of AT1R silencing on IRS-1 and IRS-2 expression. Islets of $\mathrm{db} / \mathrm{db}$ mice were transfected with Ad-si AT1R, Ad-siControl, or Mock and cells were cultured for $72 \mathrm{~h}$ prior to quantitative immunoblot evaluation. Results are represented as mean \pm SD for six independent experiments. ${ }^{*} P<0.05$ versus Ad-siControl.

3.2. Reduction of AT1R by Ad-shRNA-AT1R Treatment. The islets treated with Ad-siAT1R exhibited a $75 \%$ reduction in AT1R mRNA compared with ones treated with Ad-siControl $(P<0.05)$. Moreover, immunoblot analysis demonstrated a $65 \%$ decrease in AT1R immunoreactivity in the total extract $(P<0.05)$ (Figure 2). Altogether, these data validated that the RNA interference (RNAi) strategy was effective to suppress the expression of intraislet AT1R.

3.3. Improved Insulin Sensitivity in $\beta$-Cells by Ad-siAT1R Treatment in Islets of $d b / d b$ Mice. Western blot showed that islets treated with Ad-siAT1R manifested significant increased protein levels of IRS-1 (by 85\%), IRS-2 (by 95\%), PI3-K(85) (by $112.5 \%$ ), and p-Akt2 (by 164\%) when compared with ones treated with Ad-siControl $(P<0.05)$ (Figures 3 and 4$)$, which indicated that inhibition of AT1R by RNAi improved insulin sensitivity of $\beta$-cells.

3.4. Improved GSIS by Ad-siAT1R Treatment in Islets of $d b / d b$ Mice. The insulin secretion stimulated by lower $(2.8 \mathrm{mM})$ or higher $(16.7 \mathrm{mM})$ glucose concentration was measured in 


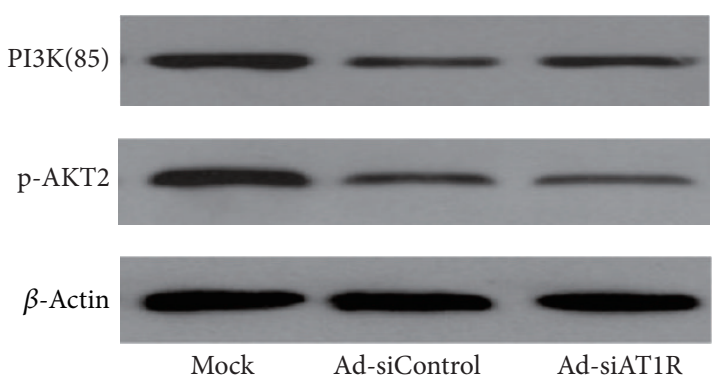

(a)

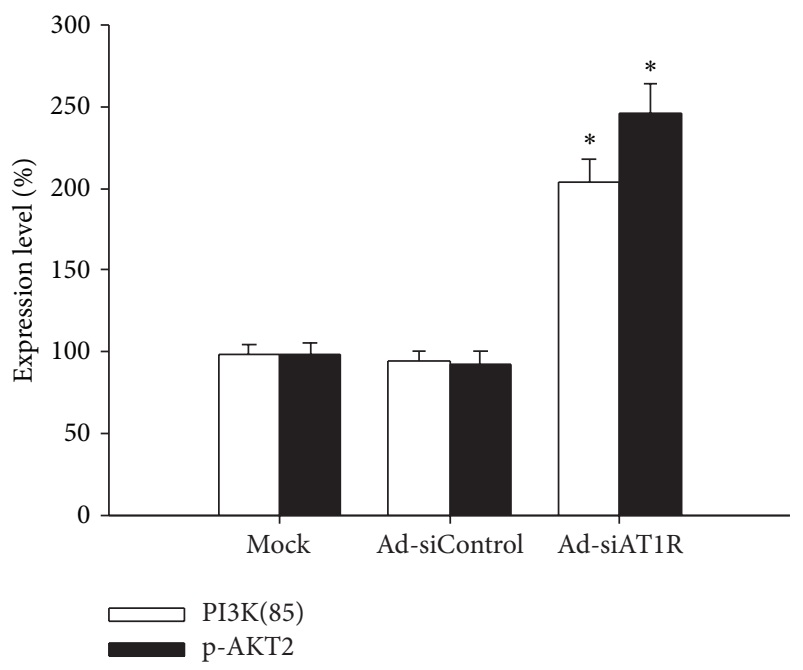

(b)

FIgURE 4: Effects of AT1R silencing on PI3-K(85) and p-Akt2 expression. Islets of $\mathrm{db} / \mathrm{db}$ mice were transfected with Ad-si AT1R, Ad-siControl, or Mock and cells were cultured for $72 \mathrm{~h}$ prior to quantitative immunoblot evaluation. Results are represented as mean \pm SD for six independent experiments. ${ }^{*} P<0.05$ versus AdsiControl.

uninfected cells and cells infected with Ad-siAT1R and AdsiControl. No significant differences were observed between Ad-siAT1R group and Ad-siControl group at $2.8 \mathrm{mM}$ glucose. Contrarily, there was a significant improvement of insulin secretion response at $16.7 \mathrm{mM}$ glucose (SR $6.1 \pm 1.0$ ) in AdsiAT1R group compared with Mock group (SR $2.3 \pm 0.6)$ or Ad-siControl group (SR $2.0 \pm 0.4)(P<0.01)$ (Figure 5).

Perifusion is a golden method to evaluate the first-phase insulin secretion of islet in vitro. Islets of $\mathrm{db} / \mathrm{db}$ mice manifested only a slight elevation of insulin secretion, while islets treated with Ad-siAT1R showed a pronounced increase in insulin peak at 1 minute after $16.7 \mathrm{mM}$ glucose loaded $(P<$ 0.05) (Figure 6).

3.5. Reduction of Glucagon Secretion by by Ad-siAT1R Treatment in Islets of $d b / d b$ Mice. The Glucagon secretion was assayed in vitro by islet perifusion. Persistently elevated levels of glucagon were observed in Ad-siControl group, while AdsiAT1R group showed a significant reduction of glucagon secretion since being stimulated by $16.7 \mathrm{mM}$ glucose solution compared with Ad-siControl group $(P<0.05)$ (Figure 7).

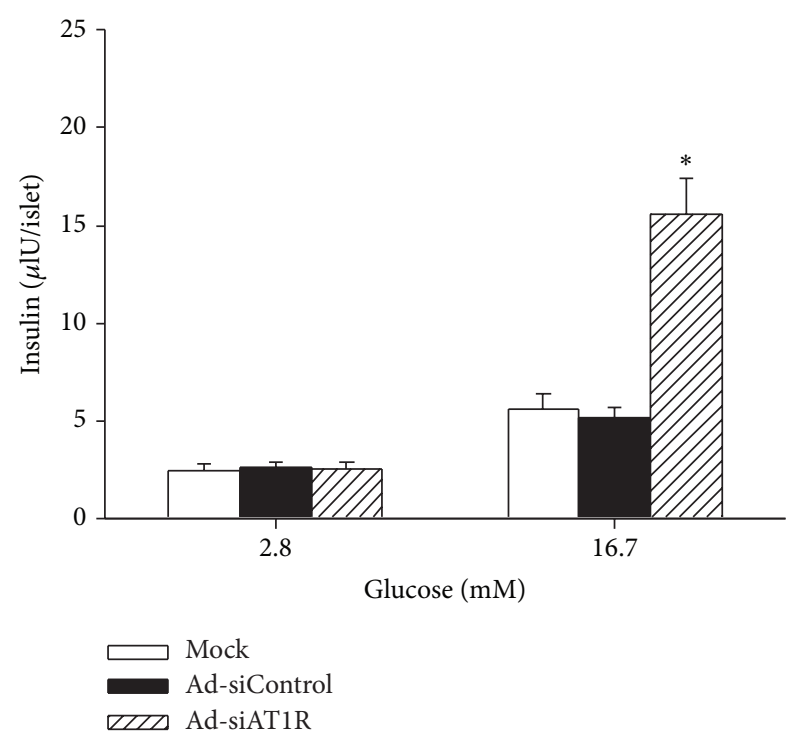

FIGURE 5: Effect of AT1R silencing on insulin secretion in islets. Islets were treated with Ad-siAT1R, Ad-siControl, or Mock, and $72 \mathrm{~h}$ later, insulin secretion was measured at basal and stimulatory glucose. Results are represented as mean \pm SD for six independent experiments. ${ }^{*} P<0.05$ versus Ad-siControl.

3.6. Improved Glucose-Sensing Apparatus in $\beta$-Cells. Glucose transporter-2 (GLUT-2) and glucokinase (GCK) have been considered main components of $\beta$-cell glucose-sensing apparatus. Thus, we further investigated the expression levels of GLUT-2 and GCK in islets. By Western blot, significant decrease in both GLUT-2 (by 65.8\%) and GCK (by 62.7\%) was found in $\mathrm{db} / \mathrm{db}$ mice when compared with $\mathrm{db} / \mathrm{m}$ mice $(P<$ 0.05 ) (Figure 8). In parallel with the reduction of AT1R expression, the expression of GLUT-2 and GCK increased by $190 \%$ and $121 \%$, respectively, in islets treated with Ad-siAT1R, compared with ones treated with Ad-siControl $(P<0.05)$ (Figure 9).

\section{Discussion}

RAS components have long been known to express locally in rodent and human islets. The role of local RAS in islet function has become the focus of recent research, ever since Chappell MC and his colleagues discovered intrinsic angiotensin system in dog exocrine pancreas approximately 20 years ago [19]. The local pancreatic RAS has been shown to be upregulated in diabetic animals, whereas treatment with RAS blockade can improve $\beta$-cell function and glucose tolerance in variety of studies [20-22]. But the common RAS blockade usually inhibits the RAS systemically rather than locally. So we can not exclude the possibility that these benefits were dependent on the changes of systemic circulating RAS components due to the defects of previous experiment design. In the present study, we indeed inhibited the expression of intraislet AT1R by means of RNAi, a specific and efficient way for gene silencing. We successfully downregulated the expression of AT1R in islet and found not only notable improvement 


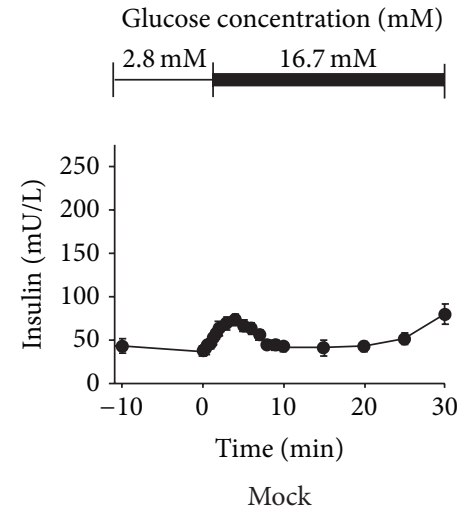

(a)

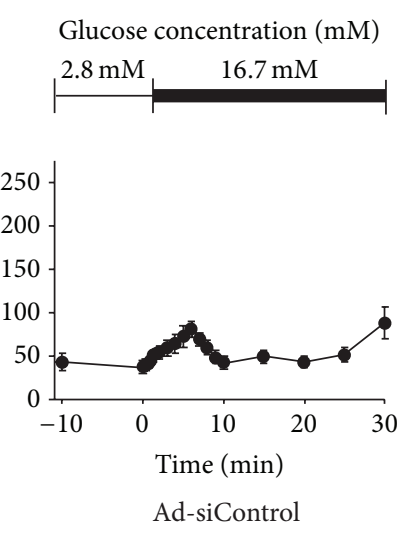

(b)

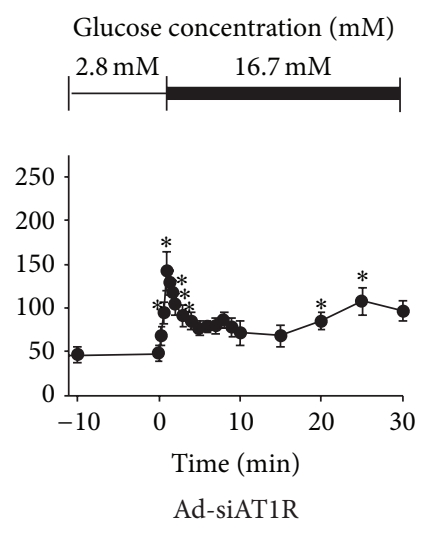

(c)

FIGURE 6: Insulin secretion by islet perifusion in Ad-siAT1R, Ad-siControl and Mock group. Results are represented as mean \pm SD for three duplicate experiments. ${ }^{*} \mathrm{P}<0.05$ versus Ad-siControl.

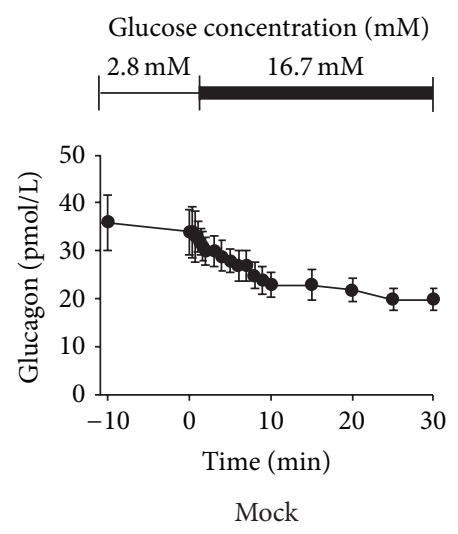

(a)
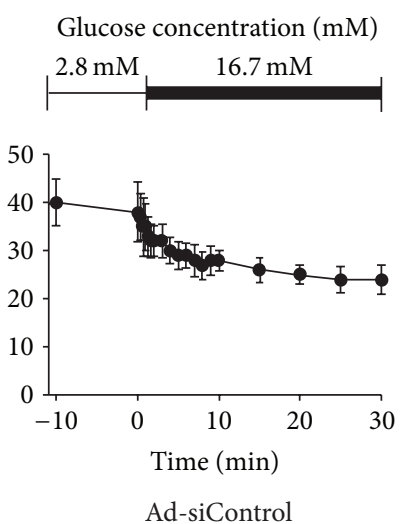

(b)
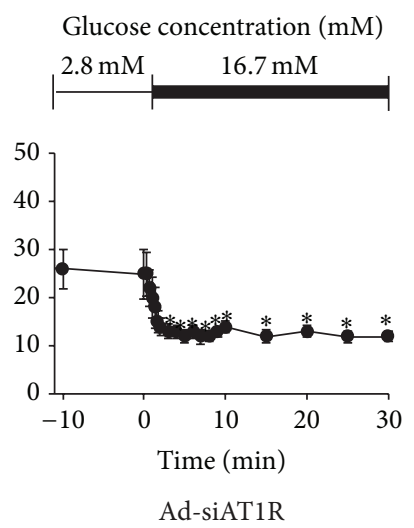

(c)

FIGURE 7: Glucagon secretion by islet perifusion in Ad-siAT1R, Ad-siControl, and Mock group. Results are represented as mean \pm SD for three duplicate experiments. ${ }^{*} P<0.05$ versus Ad-siControl.

of first-phase insulin secretion but also significant reduction of glucagon secretion in Ad-siAT1R group. What is more, our results showed that improvement of islet function by blocking intraislet AT1R is associated with a detectable increased IRS1, IRS-2, PI3-kinase p85, and phospho-Akt2 expression levels, as well as increased activities of glucose-sensing apparatus such as GLUT-2 and GCK in pancreatic islet.

The mechanisms of the protective action of RAS blockade on islet function are diverse and complicated. A study found that RAS blockade could improve microvessel density of islets and their function, suggesting that the improvement of blood supply of islets may be a crucial mechanism by which RAS blockade protects islet function [23]. Tikellis et al. [20] showed that chronic (10 weeks) RAS inhibition starting at the age of 10 weeks attenuated disordered islet architecture in Zucker diabetic fatty rats; these beneficial effects were partly attributed to decreased intraislet fibrosis, apoptosis, and oxidative stress. Meanwhile, Kwan and Leung [21] indicated that islet AT1R activation in young diabetic mice could mediate progressive islet-cell failure through UCP-driven oxidative damage. In addition, a recent finding indicated the effects of high glucose levels on islet function might be mediated by local islet RAS, partially AT2 receptors, via the alteration of $\beta$ cell potassium channels [24]. However, how RAS exerts these effects is less well documented and remains to be clarified.

Several recent studies have indicated that $\beta$-cells express components of insulin signaling systems including insulin receptors, insulin receptor substrates (IRS-1 and IRS-2), phosphatidylinositol 3-kinase (PI3-K), and protein kinase B [2527]. IRS- 1 and IRS- 2 molecules are key mediators in insulin and IGF-1 signaling and their importance in $\beta$-cell physiology has been proven by several studies. Firstly, insulin binds to receptors on the surfaces of $\beta$-cells and causes tyrosine phosphorylation of the insulin receptor, IRS-1, and PI3-K. Such activation of PI3-K leads to production of PIP3. Secondly, PIP3 binds with PH domain of Akt and promotes its activation, which stimulates GLUT-2 translocation and glucose uptake into $\beta$-cells. Finally, increased intracellular glucose leads to increased production of ATP by the catalyze of GCK. The increased ATP/ADP ratio leads to closing of the potassium channel and depolarization of $\beta$-cells which leads the open of calcium channel and insulin secretion [28]. 

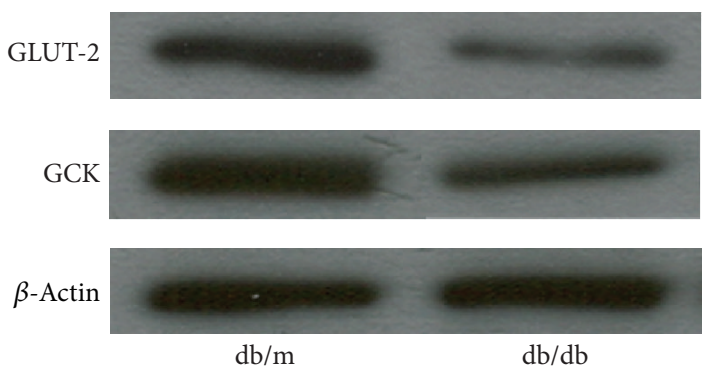

(a)

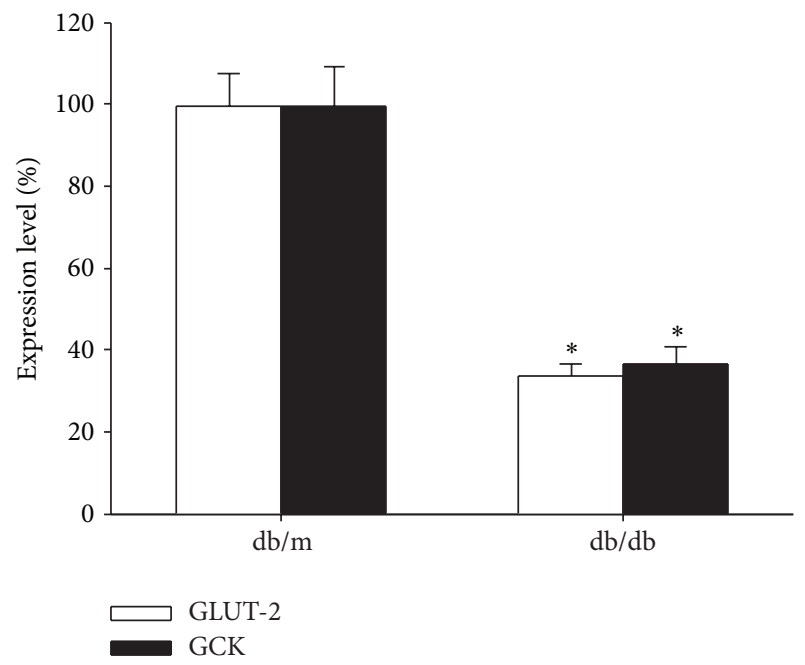

(b)

FIGURE 8: Expression of GLUT-2 and GCK protein in islets from $\mathrm{db} / \mathrm{m}$ mice or $\mathrm{db} / \mathrm{db}$ mice. Lysates from freshly isolated islets were analyzed for GLUT-2 and GCK expression by Western blot analysis. Results represent the mean \pm SD. Blots from one representative experiments are shown. ${ }^{*} P<0.05$ versus $\mathrm{db} / \mathrm{m}$ group, $n=5$.

Therefore, as insulin signal moleculars, IRS-1, PI3-K, and Akt, all play important role in GSIS. Decreased expression of IRSs or derangement in their signal transduction pathway leads to impaired insulin secretion similar to that seen in type 2 diabetes. In this study, we found that inhibition of intraislet AT1R expression resulted in notable improvement of first-phase insulin secretion with significantly increased protein levels of IRS-1, IRS-2, PI3-K p85, and phosphorylated Akt. Such result suggests that IR/IRSs/PI3-K/Akt may act as a potential link between intraislet RAS activity and GSIS.

As mentioned above, both GLUT-2 and GCK are glucosesensing apparatus of $\beta$-cell acting as important roles in GSIS. GSIS is initiated by the uptake of glucose by the translocation of glucose transporter GLUT-2 in pancreatic beta cell. It is suggested that GLUT-2-null mice are hyperglycemic and hypoinsulinemic with a loss of first-phase glucose-stimulated insulin secretion and die within the first 3 weeks of life [29]. Furthermore, GCK is the rate-limiting step in glucose metabolism by $\beta$-cells, and it therefore has a high control strength over the entire process of glucose utilization, glucose oxidation, and insulin secretion. The discovery that GCK

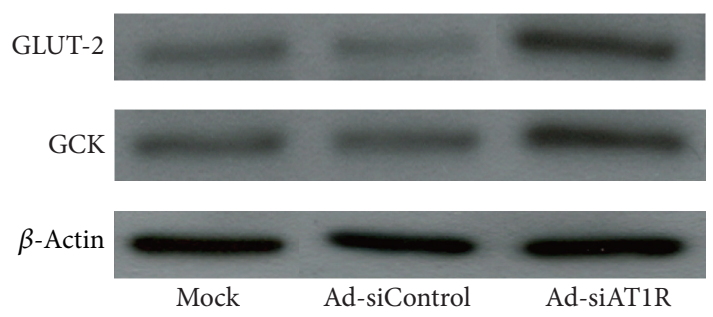

(a)

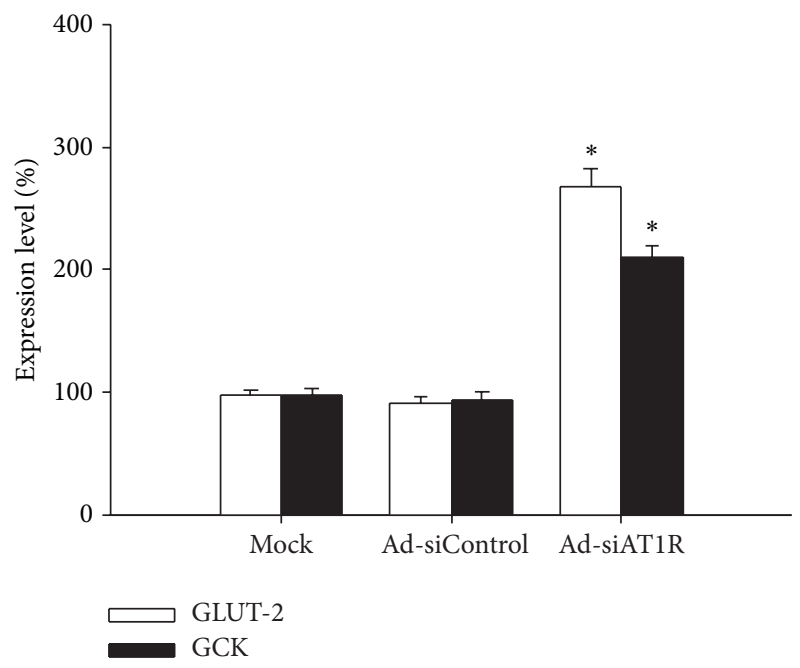

(b)

Figure 9: Effects of AT1R silencing on GLUT-2 and GCK expression. Islets of $\mathrm{db} / \mathrm{db}$ mice were transfected with Ad-si AT1R, AdsiControl, or Mock and cells were cultured for $72 \mathrm{~h}$ prior to immunoblot evaluation of GLUT-2 and GCK. Results are represented as mean $\pm \mathrm{SD}$ for six independent experiments. ${ }^{*} P<0.05$ versus Ad-siControl.

gene mutations account for many of the cases of maturityonset diabetes of youth (MODY) has pointed out the pivotal role played by this enzyme in glucose homeostasis [30, 31]. Im Walde et al. have found that the GCK mRNA decreased by $50 \%$ in pancreas of diabetic mice compared with normal mice [32]. Here we show that GLUT-2 and GCK expression in $\mathrm{db} / \mathrm{db}$ mice are significantly lower than that in $\mathrm{db} / \mathrm{m}$ mice, while being restored after AT1R inhibition by Ad-siAT1R. In summary, we can conclude that AT1R inhibition improves GSIS by restoring $\beta$-cell insulin sensitivity and downstream glucose-sensing apparatus, while the detailed mechanism remains to be further investigated in future work.

A few researches have revealed the mechanisms of AngIImediated insulin resistance. AngII could exert its influence on insulin sensitivity via the AT1 receptor in at least three ways. Firstly, AngII directly inhibits tyrosine-phosphorylation of IRS-1 and increases serine phosphorylation of IRS-1 and PI3-K p85 regulatory subunit [33]. Secondly, AngII indirectly dephosphorylates IR and IRS-1 by activating TNF- $\alpha$ and protein tyrosine phosphatase (PTP)-1B [34]. Furthermore, AngII-induced oxidative stress impairs activity of PI3$\mathrm{K}$ and its downstream signaling, including AKT2-mediated 
GLUTs translocation and expression levels of other glucosesensing apparatus [35]. Therefore, in our study, AT1R inhibition induced increased tyrosine phosphorylation of IRS1 and PI3-K p85 regulatory subunit may contribute to the improvement of $\beta$-cell insulin sensitivity. And since our previous study showed the expression levels of oxidative stress markers in islet of $\mathrm{db} / \mathrm{db}$ mice decreased with candesartan treatment, the alleviation of oxidative stress may be also an impact factor of $\beta$-cell insulin sensitivity and downstream glucose-sensing apparatus expression.

For the first time, we evaluated glucagon dynamic secretion by perifusion and found significantly reduction of glucagon secretion in Ad-siAT1R group. Glucagon is the principal counterregulatory hormone that opposes insulin action leading to coordinate bihormonal control of glucose homeostasis. Increasing evidence has suggested that increased glucagon secretion is implicated in the development of T2DM [36]. A study just published in July showed that enalapril appeared to reduce hyperglucagonemia in high fat dietinduced insulin resistant mice [37]. But the mechanism by which glucagon secretion is inhibited by RAS block is far from clear. Consistent with an important role for insulin in the $\beta$ cell, insulin receptor and the insulin-signaling molecules are expressed highly in pancreatic $\alpha$-cells and play an important role in modulating $\alpha$-cell function [38-42]. The insulin receptor defects in the insulin-signaling pathway of pancreatic $\alpha$ cell may contribute to the development of diabetic hyperglucagonemia, manifesting as blunted insulin-stimulated Akt phosphorylation and insulin-suppressed glucagon secretion [43]. Therefore, it is conceivable that AT1R block could attenuate hyperglucagonemia by restoring insulin suppression of glucagon secretion driven by insulin, mainly through improved first-phase insulin secretion (indirect) and insulin sensitivity of $\alpha$-cell (direct). Yet the detailed mechanisms remain to be further explored in future research using islet $\alpha$-cell strain.

In conclusion, our study suggests that intraislet AT1R is a crucial physiological regulator of insulin sensitivity of $\beta$ cell and thus affects glucose-induced insulin release. We also found that intraislet inhibition of AT1R expression led to downregulation of glucagon secretion from isolated islets of $\mathrm{db} / \mathrm{db}$ mice. The characteristics of AT1R inhibitors in both insulin and glucagon secretion could make it a potential novel therapeutics for the prevention and treatment of type 2 diabetes.

\section{Abbreviations}

AT1R: Angiotensin II type 1 receptor

GSIS: Glucose-stimulated insulin secretion

IRS: Insulin receptor substrates

GCK: Glucokinase

GLUT-2: Glucose transporter-2

ACEI: ACE inhibitor

ARB: Angiotensin receptor blocker

AGT: Angiotenogen

PI3-K: Phosphatidylinositol 3-kinase

Akt: $\quad$ Protein kinase B

PDK-1: Phosphoinositide-dependent kinase-1.

\section{Conflict of Interests}

The authors declare that they have no conflict of interests regarding the publication of this paper.

\section{Authors' Contribution}

Zhen Zhang and Chunyan Liu contributed equally to this study.

\section{Acknowledgments}

This study was supported by National Natural Science Foundation of China (no. 81000568, no. 81173622, and no. 30900697), Jiangsu Provincial Natural Science Foundation (no. BK2012781), and Science Foundation of Nanjing Military Command (no. 11MA100).

\section{References}

[1] L. Hansson, L. H. Lindholm, L. Niskanen et al., "Effect of angiotensin-converting-enzyme inhibition compared with conventional therapy on cardiovascular morbidity and mortality in hypertension: the Captopril Prevention Project (CAPPP) randomised trial," The Lancet, vol. 353, no. 9153, pp. 611-616, 1999.

[2] R. Andraws and D. L. Brown, "Effect of inhibition of the Reninangiotensin system on development of type 2 diabetes mellitus (meta-analysis of randomized trials)," American Journal of Cardiology, vol. 99, no. 7, pp. 1006-1012, 2007.

[3] B. Dahlöf, R. B. Devereux, S. E. Kjeldsen et al., "Cardiovascular morbidity and mortality in the Losartan Intervention For Endpoint reduction in hypertension study (LIFE): a randomised trial against atenolol," The Lancet, vol. 359, no. 9311, pp. 9951003, 2002.

[4] A. J. Scheen, "Renin-angiotensin system inhibition prevents type 2 diabetes mellitus: part 1. A meta-analysis of randomised clinical trials," Diabetes and Metabolism, vol. 30, no. 6, pp. 487496, 2004.

[5] M. Tahmasebi, J. R. Puddefoot, E. R. Inwang, and G. P. Vinson, "The tissue renin-angiotensin system in human pancreas," Journal of Endocrinology, vol. 161, no. 2, pp. 317-322, 1999.

[6] P. O. Carlsson, "The renin-angiotensin system in the endocrine pancreas," Journal of the Pancreas, vol. 2, no. 1, pp. 26-32, 2001.

[7] H. Montgomery, S. E. Humphries, and P. S. Leung, "Reninangiotensin systems: the new frontier," International Journal of Biochemistry and Cell Biology, vol. 35, no. 6, p. 758, 2003.

[8] C. Kampf, T. Lau, R. Olsson, P. S. Leung, and P.-O. Carlsson, "Angiotensin II type 1 receptor inhibition markedly improves the blood perfusion, oxygen tension and first phase of glucosestimulated insulin secretion in revascularised syngeneic mouse islet grafts," Diabetologia, vol. 48, no. 6, pp. 1159-1167, 2005.

[9] P. S. Leung and P. O. Carlsson, "Pancreatic islet renin angiotensin system: its novel roles in islet function and in diabetes mellitus," Pancreas, vol. 30, no. 4, pp. 293-298, 2005.

[10] J. Shao, N. Iwashita, H. Du et al., "Angiotensin II receptor blocker provides pancreatic $\beta$-cell protection independent of blood pressure lowering in diabetic db/db mice," Acta Pharmacologica Sinica, vol. 28, no. 2, pp. 246-257, 2007.

[11] J. Shao, N. Iwashita, F. Ikeda et al., "Beneficial effects of candesartan, an angiotensin II type 1 receptor blocker, on $\beta$ cell function and morphology in $\mathrm{db} / \mathrm{db}$ mice," Biochemical and 
Biophysical Research Communications, vol. 344, no. 4, pp. 12241233, 2006.

[12] L. D. Klaman, O. Boss, O. D. Peroni et al., "Increased energy expenditure, decreased adiposity, and tissue-specific insulin sensitivity in protein-tyrosine phosphatase 1B-deficient mice," Molecular and Cellular Biology, vol. 20, no. 15, pp. 5479-5489, 2000.

[13] P. L. Rothenberg, L. D. Willison, J. Simon, and B. A. Wolf, "Glucose-induced insulin receptor tyrosine phosphorylation in insulin- secreting $\beta$-cells," Diabetes, vol. 44, no. 7, pp. 802-809, 1995.

[14] M. C. Harbeck, D. C. Louie, J. Howland, B. A. Wolf, and P. L. Rothenberg, "Expression of insulin receptor mRNA and insulin receptor substrate 1 in pancreatic islet $\beta$-cells," Diabetes, vol. 45 , no. 6, pp. 711-717, 1996.

[15] I. B. Leibiger, B. Leibiger, T. Moede, and P. Berggren, "Exocytosis of insulin promotes insulin gene transcription via the insulin receptor/PI-3 kinase/p70 s6 kinase and CaM kinase pathways," Molecular Cell, vol. 1, no. 6, pp. 933-938, 1998.

[16] G. G. Xu, Z. Gao, P. D. Borge Jr., and B. A. Wolf, "Insulin receptor substrate 1-induced inhibition of endoplasmic reticulum Ca2+ uptake in $\beta$-cells: autocrine regulation of intracellular $\mathrm{Ca} 2+$ homeostasis and insulin secretion," Journal of Biological Chemistry, vol. 274, no. 25, pp. 18067-18074, 1999.

[17] J. Ran, T. Hirano, and M. Adachi, "Chronic ANG II infusion increases plasma triglyceride level by stimulating hepatic triglyceride production in rats," American Journal of PhysiologyEndocrinology and Metabolism, vol. 287, no. 5, pp. E955-E961, 2004.

[18] A. D. de Kloet, E. G. Krause, and S. C. Woods, "The renin angiotensin system and the metabolic syndrome," Physiology and Behavior, vol. 100, no. 5, pp. 525-534, 2010.

[19] M. C. Chappell, "Characterization of angiotensin II receptor subtypes in pancreatic acinar AR42J cells," Peptides, vol. 16, no. 4, pp. 741-747, 1995.

[20] C. Tikellis, P. J. Wookey, R. Candido, S. Andrikopoulos, M. C. Thomas, and M. E. Cooper, "Improved islet morphology after blockade of the Renin-angiotensin system in the ZDF rat," Diabetes, vol. 53, no. 4, pp. 989-997, 2004.

[21] Y. C. Kwan and P. S. Leung, "Angiotensin II type 1 receptor antagonism mediates uncoupling protein 2-driven oxidative stress and ameliorates pancreatic islet $\beta$-cell function in young type 2 diabetic mice," Antioxidants and Redox Signaling, vol. 9, no. 7, pp. 869-878, 2007.

[22] L. Yuan, L. Xin, G. Xu et al., "Effect of renin-andiotensin system blockade in islet function in diabetic rats," Journal of Endocrinological Investigation, vol. 33, no. 1, pp. 13-19, 2010.

[23] X. Li, L. Yuan, G. Xu et al., "Effect of renin angiotensin system blockade on the islet microvessel density of diabetic rats and its relationship with islet function," Journal of Huazhong University of Science and Technology, vol. 29, no. 6, pp. 684-688, 2009.

[24] K. Y. Chu, Q. Cheng, C. Chen et al., "Angiotensin II exerts glucose-dependent effects on $\mathrm{Kv}$ currents in mouse pancreatic $\beta$-cells via angiotensin II type 2 receptors," American Journal of Physiology, vol. 298, no. 2, pp. C313-C323, 2010.

[25] G. G. Xu, Z. Gao, P. D. Borge Jr., and B. A. Wolf, "Insulin receptor substrate 1-induced inhibition of endoplasmic reticulum Ca2+ uptake in $\beta$-cells: autocrine regulation of intracellular $\mathrm{Ca} 2+$ homeostasis and insulin secretion," Journal of Biological Chemistry, vol. 274, no. 25, pp. 18067-18074, 1999.

[26] S. I. Taylor, “Deconstructing type 2 diabetes," Cell, vol. 97, no. 1, pp. 9-12, 1999.
[27] N. S. Kalupahana and N. Moustaid-Moussa, "The reninangiotensin system: a link between obesity, inflammation and insulin resistance," Obesity Reviews, vol. 13, no. 2, pp. 136-149, 2012.

[28] C. A. Aspinwall, W. Qian, M. G. Roper, R. N. Kulkarni, C. R. Kahn, and R. T. Kennedy, "Roles of insulin receptor substrate-1, phosphatidylinositol 3-kinase, and release of intracellular Ca2+ stores in insulin-stimulated insulin secretion in $\beta$-cells," Journal of Biological Chemistry, vol. 275, no. 29, pp. 22331-22338, 2000.

[29] M. T. Guillam, E. Hümmler, E. Schaerer et al., "Early diabetes and abnormal postnatal pancreatic islet development in mice lacking Glut-2," Nature Genetics, vol. 17, no. 3, pp. 327-330, 1997.

[30] P. Spégel, E. Ekholm, T. Tuomi et al., "Metabolite profiling reveals normal metabolic control in carriers of mutations in the glucokinase gene (MODY2)," Diabetes, vol. 62, no. 2, pp. 653661, 2013.

[31] M. Capuano, C. M. Garcia-Herrero, N. Tinto et al., "Glucokinase (GCK) mutations and their characterization in MODY2 children of Southern Italy," PLoS ONE, vol. 7, no. 6, Article ID e38906, 2012.

[32] S. S. Im Walde, S. C. Dohle, P. Schott-Ohly, and H. Gleichmann, "Molecular target structures in alloxan-induced diabetes in mice," Life Sciences, vol. 71, no. 14, pp. 1681-1694, 2002.

[33] A. J. Scheen, "Renin-angiotensin system inhibition prevents type 2 diabetes mellitus: part 2. Overview of physiological and biochemical mechanisms," Diabetes and Metabolism, vol. 30, no. 6, pp. 498-505, 2004.

[34] F. Andreozzi, E. Laratta, A. Sciacqua, F. Perticone, and G. Sesti, "Angiotensin II impairs the insulin signaling pathway promoting production of nitric oxide by inducing phosphorylation of insulin receptor substrate-1 on Ser12 and Ser616 in human umbilical vein endothelial cells," Circulation Research, vol. 94, no. 9, pp. 1211-1218, 2004.

[35] S. O. Kasper, E. E. Phillips, S. M. Castle, B. J. Daley, B. L. Enderson, and M. D. Karlstad, "Blockade of the renin-angiotensin system improves insulin receptor signaling and insulin-stimulated skeletal muscle glucose transport in burn injury," Shock, vol. 35, no. 1, pp. 80-85, 2011.

[36] B. E. Dunning and J. E. Gerich, "The role of $\alpha$-cell dysregulation in fasting and postprandial hyperglycemia in type 2 diabetes and therapeutic implications," Endocrine Reviews, vol. 28, no. 3, pp. 253-283, 2007.

[37] E. D. C. Frantz, C. Crespo-Mascarenhas, A. R. C. BarretoVianna et al., "Renin-angiotensin system blockers protect pancreatic islets against diet-induced obesity and insulin resistance in mice," PLoS ONE, vol. 8, no. 7, Article ID e67192.

[38] Y. C. Patel, M. Amherdt, and L. Orci, "Quantitative electron microscopic autoradiography of insulin, glucagon, and somatostatin binding sites on islets," Science, vol. 217, no. 4565, pp. 11551156, 1982.

[39] S. J. Bhathena, H. K. Oie, and A. F. Gazdar, "Insulin, glucagon, and somatostatin receptors on cultured cells and clones from rat islet cell tumor," Diabetes, vol. 31, no. 6, pp. 521-531, 1982.

[40] K. Kisanuki, H. Kishikawa, E. Araki et al., "Expression of insulin receptor on clonal pancreatic alpha cells and its possible role for insulin-stimulated negative regulation of glucagon secretion," Diabetologia, vol. 38, no. 4, pp. 422-429, 1995.

[41] L. A. Velloso, E. M. Carneiro, S. C. Crepaldi, A. C. Boschero, and M. J. A. Saad, "Glucose- and insulin-induced phosphorylation of the insulin receptor and its primary substrates IRS-1 and IRS2 in rat pancreatic islets," FEBS Letters, vol. 377, no. 3, pp. 353$357,1995$. 
[42] K. Kaneko, T. Shirotani, E. Araki et al., "Insulin inhibits glucagon secretion by the activation of PI3-kinase in In-R1-G9 cells," Diabetes Research and Clinical Practice, vol. 44, no. 2, pp. 83-92, 1999.

[43] E. Xu, M. Kumar, Y. Zhang et al., "Intra-islet insulin suppresses glucagon release via GABA-GABAA receptor system," Cell Metabolism, vol. 3, no. 1, pp. 47-58, 2006. 


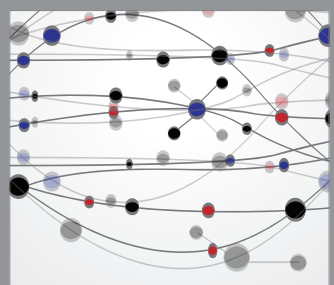

The Scientific World Journal
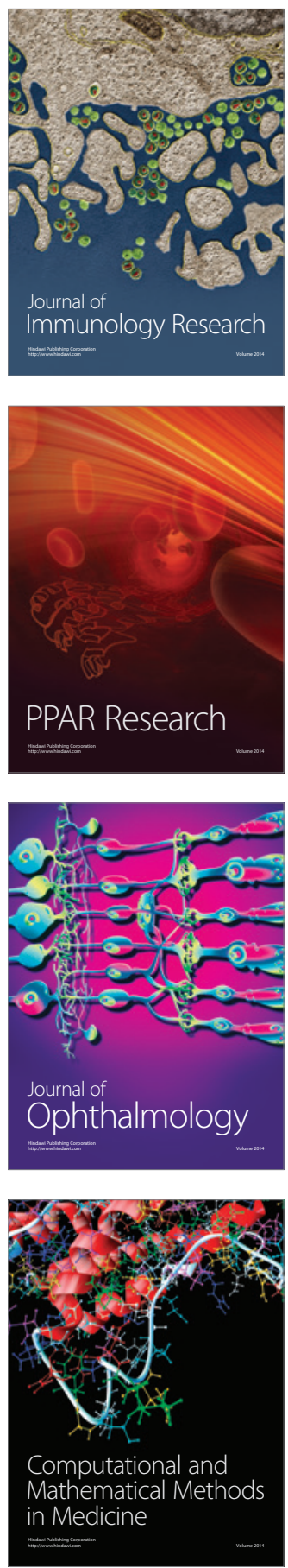

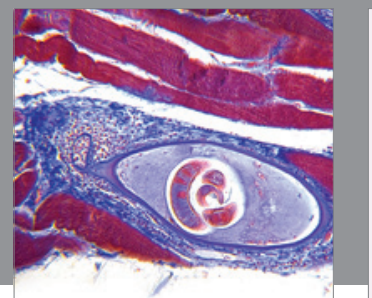

Gastroenterology

Research and Practice
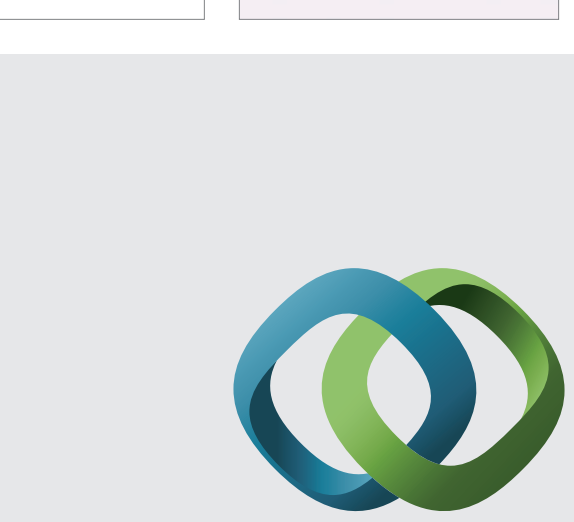

\section{Hindawi}

Submit your manuscripts at

http://www.hindawi.com
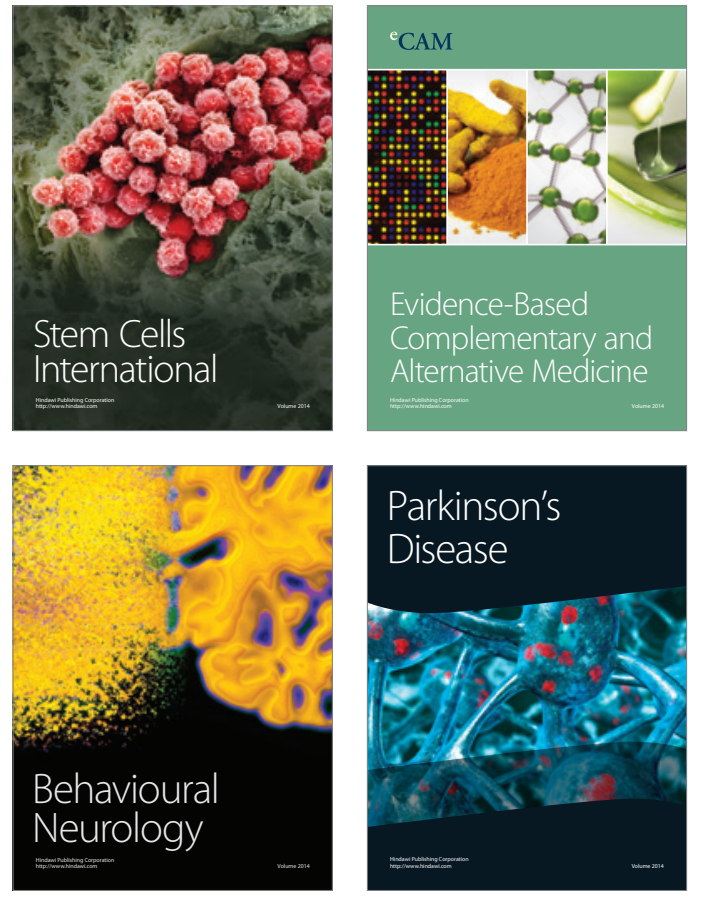
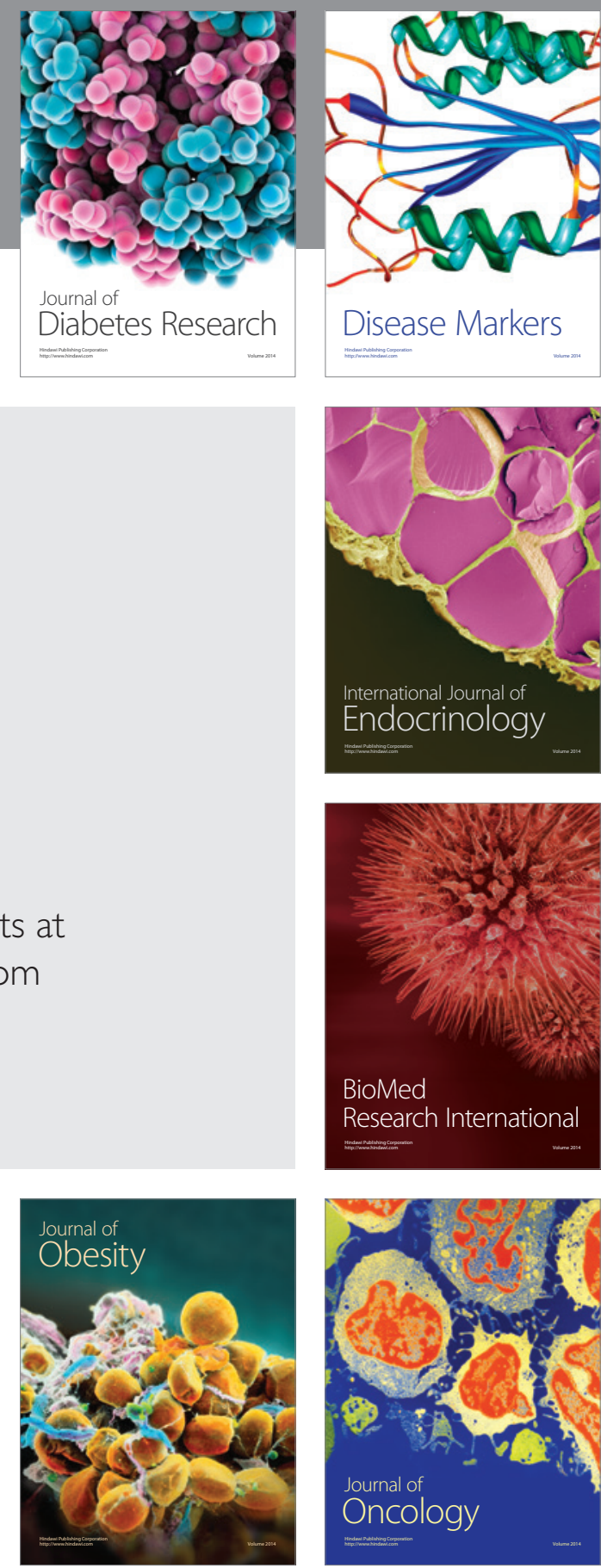

Disease Markers
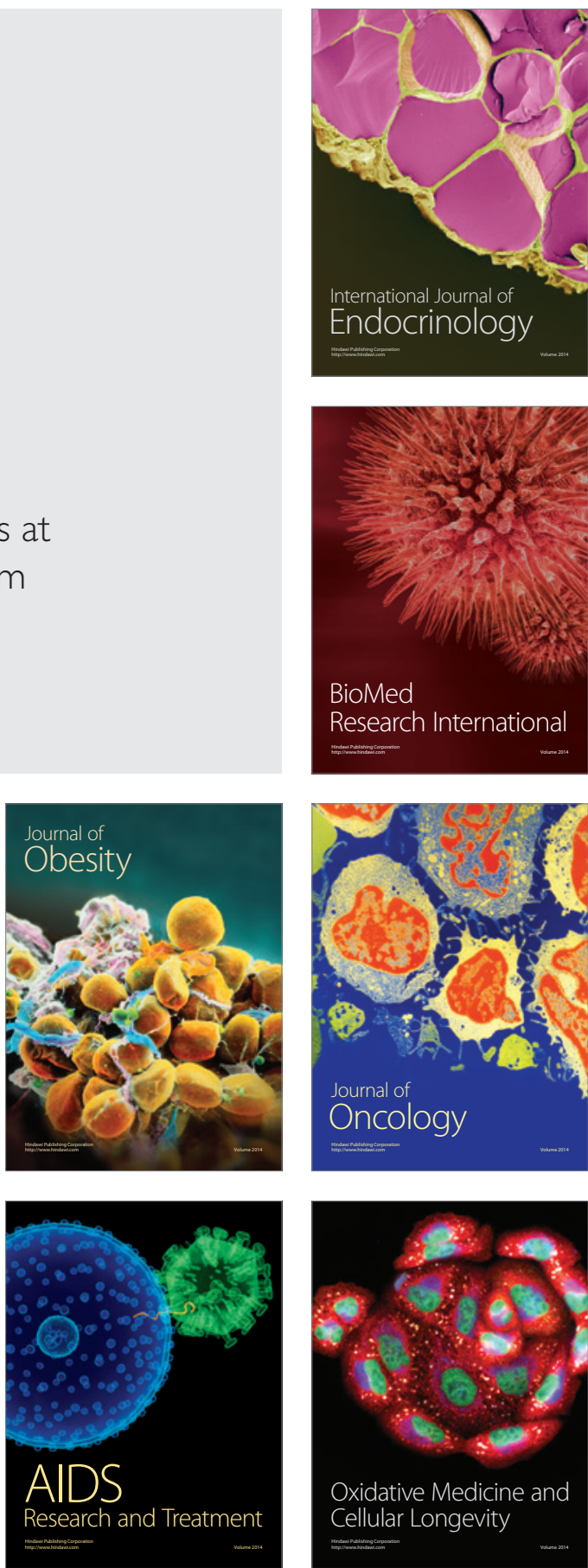